Rafał Rybacki ${ }^{1}$

Archiwum Archidiecezjalne w Poznaniu, Polska

\title{
Historia jako szczególne wyzwanie Kościoła w ujęciu Józefa Nowackiego i Mariana Banaszaka
}

\section{Ku integralności historii Kościoła jako nauki}

Podejmując zagadnienie historii jako szczególnego wyzwania Kościoła w ujęciu ks. Józefa Nowackiego (zm. 1964) i ks. Mariana Banaszaka (zm. 1997), należy najpierw uzasadnić pokrótce słuszność tak sformułowanej kwestii. Na czym polega specyfika historii w rzeczywistości Kościoła katolickiego? Co to znaczy, że historia jest wyzwaniem dla Kościoła, a także w czym tkwi szczególność tegoż wyzwania? Odpowiedź na te pytania nie może pominąć zjawisk i procesów, jakie zaistniały w historiografii kościelnej XIX stulecia. Zarówno ks. Józef Nowacki, jak i jego uczeń ks. Marian Banaszak jako badacze dziejów Kościoła katolickiego byli spadkobiercami tendencji, dzięki którym historia Kościoła zdobywała coraz więcej metodologicznej samodzielności w strukturze pozostałych gałęzi wiedzy teologicznej. W rozległym chronologicznie i złożonym procesie tej emancypacji historii jako nauki nie sposób nie wspomnieć dzieła Jeana Mabillona De Re diplomatica libri $V I^{2}$, które ukazało się w Paryżu w 1681 roku. Poglądy Mabillona stanowiły początek nowego podejścia do kwestii dokumentu średniowiecznego i nadały temuż dokumentowi nowy status w świecie nowożytnych „bella diplomatica”3.

W 1881 roku papież Leon XIII nakazał otwarcie Archivum Secretum Apostolicum Vaticanum dla uczonych, niezależnie od ich światopoglądu czy proweniencji $^{4}$. Decyzja Leona XIII była przełomowym aktem, którego jednym z pierwszych

${ }^{1}$ Ksiądz Rafał Rybacki — od 2006 roku kustosz Archiwum Archidiecezjalnego w Poznaniu; e-mail: kustosz@aap.poznan.pl. ORCID: 0000-0002-6799-9328.

2 J. Mabillon, De Re diplomatica libri VI [...], Paryż 1681.

3 Szerzej na ten temat, zob. M. Dorna, Mabillon i inni. Rzecz o powstaniu dyplomatyki, Poznań 2014.

${ }^{4}$ Szerzej na ten temat, zob. G. Martina, L'apertura dell'Archivio Vaticano. Il significato di un centenario, „Archivum Historiae Pontificiae”, 19 (1981), s. 239-307. 
owoców było rozpoczęcie w 1901 roku monumentalnej edycji źródłowej, zatytułowanej Concilium Tridentinum. Diariorum, Actorum, Epistolarum, Tractatuum nova collectio, wydawanej do 1961 roku przez Societas Goerresiana we Fryburgu Bryzgowijskim5. Inne, niemożliwe do przemilczenia świetlane momenty tegoż procesu edycji źródeł to prace Paulusa Fridolina Kehra (zm. 1944), który patronował edycji Regesta Pontificum Romanorum, w tym m.in. Italia Pontificia ${ }^{6}$, oraz Kodeksy dyplomatyczne ziem polskich, wśród których niezwykle ważne miejsce dla badań nad dziejami Kościoła w Wielkopolsce posiada Codex diplomaticus Maioris Poloniae, wydawany w latach 1877-1999, początkowo pod egidą Poznańskiego Towarzystwa Przyjaciół Nauk7 .

\section{Poznanie źródel jako fundament nauk historycznych}

Jest rzeczą niewymagającą formalnego uzasadnienia, że ks. Józef Nowacki, urodzony w 1895 roku, kiedy rozpoczynał w 1917 roku studia specjalistyczne w Münster i uczestniczył w seminariach naukowych z historii Kościoła oraz z filologii klasycznej, był niejako naocznym świadkiem tendencji, które kazały wyjść refleksji historycznej poza ramy ukształtowanej przez traktaty dogmatyki „cogitationis catholicae fidei”. Niezwykle trafny komentarz, ilustrujący ówczesną świadomość co do historii Kościoła znajdujemy u Huberta Jedina. Urodzony w 1900 roku wybitny uczony niemiecki w swym studium poświęconym kardynałowi Girolamowi Seripando, opublikowanym w Würzburgu w 1937 roku, zamieścił następującą uwagę, będącą reminiscencją jego spotkań z Benedettem Croce, który mu wyznał: ,[o]d trzech stuleci mamy tu pośmiertne dzieło Seripan$\mathrm{da}$, ale nikt $\mathrm{z}$ naszych duchownych nie zainteresował się tym. Musiał pan przyjechać $\mathrm{z}$ Niemiec, aby to dzieło dogłębnie przestudiować $\mathrm{i}$ aby napisać biografię Seripanda, tak bardzo od lat wyczekiwaną”. Po czym Jedin stwierdził: „Benedetto Croce był uważany za antyklerykała i istotnie nim był. Odnoszę jednak wrażenie, iż za tę jego postawę w dużej mierze odpowiadała bierność dużej części duchowieństwa w dziedzinie zainteresowania naukami historycznymi”.

${ }^{5}$ Zob. Concilium Tridentinum. Diariorum, Actorum, Epistolarum, Tractatuum nova Collectio, t. 1-13, Friburgi Brisgoviae 1901-1961.

${ }^{6}$ Zob. Italia Pontificia sive repertorium privilegiorum et litterarum a Romanis Pontificibus ante annum MCLXXXXVIII Italiae ecclesiis, monasteris, civitatibus singulisque personis concessorum, t. I-VII, ed. P.F. Kehr, Berolini 1906-1925.

${ }^{7}$ Całość liczy 11 tomów. Inicjatorem edycji był Ignacy Zakrzewski, pierwszym redaktorem zaś Jan Kanty Działyński.

${ }^{8}$ H. Jedin, Girolamo Seripando. Sein Leben und Denken im Geisteskampf des 16. Jahrhunderts, t. 1-2, Würzburg 1937 [tłum. R. Rybacki]. 
Zestawiając formację intelektualną ks. Nowackiego z nowymi tendencjami historiograficznymi przełomu XIX i XX wieku, wynikającymi także z ogromnego zainteresowania, jakim historia cieszyła się na początku XX wieku w obszarze filozofiii ${ }^{9}$ można stwierdzić, że starał się on przełamać tę swoistą stagnację, wynikającą przede wszystkim z tego, co wspomniany wyżej Hubert Jedin określił jako napięcie pomiędzy ,prymatem teologicznym” a „pierwszeństwem metody historycznej" w historii Kościoła jako nauce. W 1929 roku Księgarnia św. Wojciecha wydała przetłumaczony z języka niemieckiego przez ks. Nowackiego podręcznik Gerharda Rauschena pt. Zarys patrologii. Pisma Ojców Kościoła i nauka $w$ nich zawarta ${ }^{10}$. Na przełomie lat dwudziestych i trzydziestych ks. Nowacki pisał biogramy polskie do Dictionnaire d'histoire et de géographie écclesiastique. Można powiedzieć, że francuskie kompendium, mające swe analogiczne odpowiedniki także $\mathrm{w}$ innych gałęziach wiedzy teologicznej, było znaczącym osiagnięciem z punktu widzenia wspomnianego procesu emancypacji historii Kościoła jako samodzielnej nauki. Literatura francuskojęzyczna jest w pierwszej połowie XX wieku w tym obszarze doniosła, czego dowodem jest między innymi monumentalna L'Histoire de l'Église. Depuis les origines jusqu'à nos jours, zainicjowana w pierwszej połowie lat trzydziestych XX wieku przez Augustina Fliche'a i Victora Martina. W 1939 roku w Lublinie ukazało się polskie tłumaczenie pierwszego tomu tej serii, zatytułowane Historia Kościoła od poczatku aż do naszych dni. Kościót pierwotny ${ }^{11}$. Cenną warstwą tej serii jest przytaczany materiał źródłowy, w postaci bądź samych cytatów, bądź wskazania edycji źródeł, a następnie bogatej historiografii odnoszącej się do omawianej przez autorów kwestii.

Zarysowanych powyżej tendencji $\mathrm{w}$ historiografii kościelnej nie mógł nie uwzględnić ks. Nowacki, pracując nad dziełami, stanowiącymi momenty najbardziej znaczące w jego itinerarium jako historyka Kościoła. Pierwsze z nich to bezcenna edycja źródłowa, wydana w 1950 roku jako Liber beneficiorum dioecesis Posnaniensis anni 1510, czyli Księga uposażeń diecezji poznańskiej z roku $1510^{12}$. Drugie dzieło to dwutomowa monografia, zatytułowana Dzieje Archidiecezji Poznańskiej. Stanowi ona ciągle zasadniczy punkt odniesienia dla

9 Szerzej na ten temat, zob. m.in. F. Tessitore, Introduzione allo storicismo, Roma-Bari 1999.

${ }^{10}$ G. Rauschen, Patrologie. Die Schriften der Kirchenväter und Ihr Lehrgehalt, Freiburg im Breisgau 1925, tłum. pol.: J. Nowacki, Zarys patrologii. Pisma Ojców Kościoła i nauka w nich zawarta, Poznań 1929. Warto dodać, że nie było to pierwsze tłumaczenie podręcznika Rauschena na język polski. Szerzej na ten temat zob. S. Pieszczoch, Ksiądz Józef Nowacki jako patrolog, w: Ecclesia Posnaniensis. Opuscula Mariano Banaszak septuagenario dedicata, red. F. Lenort, K. Lutyński, Poznań 1998, s. 267-272.

${ }^{11}$ Historia Kościoła od poczatku aż do naszych dni, t. 1: Kościót pierwotny, red. A. Fliche, W. Martin, thum. J. Dembińska, Z. Czerniewiczowa, Lublin 1939.

${ }^{12}$ Liber beneficiorum dioecesis Posnaniensis anni 1510, edidit Josephus Nowacki, Poznańskie Towarzystwo Przyjaciół Nauk: Wydawnictwa Źródłowe Komisji Historycznej. t. X, Poznań 1950. 
historiografii diecezji, a od 1821 roku archidiecezji poznańskiej. Ujrzała ona światło dzienne w 1959 roku. Pierwszy tom tej monumentalnej monografii jest zatytułowany Kościół katedralny w Poznaniu. Studium historyczne ${ }^{13}$. W tomie drugim Archidiecezja poznańska w granicach historycznych $i$ jej ustrój ${ }^{14}$ nakreślił, opierając swój wysiłek na wnikliwym wyszczególnieniu źródeł, ewolucję struktur i urzędów diecezjalnych. Autor przedstawionej w 1938 roku na Uniwersytecie Lwowskim rozprawy habilitacyjnej De archiepiscopi gnesnensis dignitate ac praerogativa primatiali ${ }^{15}$ postrzegał całość swych późniejszych dokonań jako rezultat prac, których pierwszym etapem było opracowanie bogatego materiału źródłowego, znajdującego się w archiwach kościelnych Poznania, Gniezna, Włocławka, a także w archiwach państwowych Poznania i Warsza$\mathrm{wy}^{16}$. Wspomnienie powyższych instytucji archiwalnych i archiwaliów będacych ich zasobami, a także osadzenie całej koncepcji swej monografii w rzetelnych kwerendach archiwalnych nie było $\mathrm{w}$ pracach ks. Nowackiego przypadkowe. Specyfika historii Kościoła w jego ujęciu to nie tylko autonomia poznania historycznego. To także oparcie formułowanych twierdzeń o rzetelną kwerendę archiwalną, dzięki której możliwe jest nakreślenie granic samego poznania historycznego. Od 1933 roku ks. Nowacki pełnił funkcję dyrektora Archiwum Archidiecezjalnego w Poznaniu. Instytucję tę powołał do istnienia w 1925 roku kardynał Edmund Dalbor. Powstanie poznańskiego archiwum poprzedziły starania Stolicy Apostolskiej jak również instytucji cywilnych, w tym Ligii Narodów, którym bardzo zależało na tym, aby po kataklizmie pierwszej wojny światowej określić stan zachowania europejskich archiwów i bibliotek, zarówno świeckich, jak i kościelnych. Pierwszy dyrektor Archiwum Archidiecezjalnego w Poznaniu, ks. Edmund Majkowski, którego ks. Nowacki był bezpośrednim następcą, w swej „Réponse au Questionnaire de la Société des Nations”"17 przedstawił ogólny stan poznańskich archiwaliów kościelnych. Dzięki kardynałowi Dalborowi dokonała się instytucjonalizacja pamięci historycznej przez roztoczenie opieki nad zgromadzonymi w dawnej Akademii Lubrańskiego dokumentami i zbiorami bibliotecznymi ${ }^{18}$. Kardynał Dalbor widział główne posłannictwo stworzonej pla-

\footnotetext{
13 J. Nowacki, Dzieje Archidiecezji Poznańskiej, t. 1: Kościół katedralny w Poznaniu. Studium historyczne, Poznań 1959.

${ }^{14}$ Tenże, Dzieje Archidiecezji Poznańskiej, t. 2: Archidiecezja Poznańska w granicach historycznych i jej ustrój, Poznań 1964.

${ }_{15}$ Tenże, De archiepiscopi gnesnensis dignitate ac praerogativa primatiali, Lwów 1937, wyd. pol.: O godności i uprawnieniach prymasowskich arcybiskupa gnieźnieńskiego, tłum. A. Strzelecka, Poznań 2008.

16 Tenże, Dzieje Archidiecezji Poznańskiej, t. 2, s. IX.

${ }_{17}$ Szerzej zob. Archiwum Archidiecezjalne w Poznaniu, Ordynariat Arcybiskupi, sygn. OA $\mathrm{X} / 15$.

${ }^{18}$ Szerzej na temat historii Archiwum Archidiecezjalnego w Poznaniu, zob. F. Lenort, $Z$ dziejów organizacji i zasobu Archiwum Archidiecezjalnego w Poznaniu, Lublin 1967.
} 
cówki naukowej w „rozwoju nauk religijnych i kościelnych”19. To właśnie dzięki funkcjonowaniu tak zorganizowanej instytucji naukowo-kulturalnej, jaką okazało się Archiwum Archidiecezjalne w Poznaniu, ks. Nowacki mógł zrealizować swą monografię o dziejach archidiecezji poznańskiej. Wydaje się, że znajomość historii jako szczególne wyzwanie Kościoła była dla ks. Nowackiego oczywista. Jak wspomniano, intelektualna formacja i tendencje w historiografii kościelnej nie pozwalały już historykowi na bycie „scriptor rerum gestarum”. Jednakże specyfikę historii jako wyzwania ks. Nowacki widział również tam, gdzie w analizach dawnych struktur i urzędów biskupstwa poznańskiego pojawiały się braki źródłowe. W jakim stopniu można było posłużyć się w dyskursie historycznym analogią, w jakim zakresie należało oprzeć twierdzenia o wyniki nauk, które wówczas - przynajmniej w powszechnym przekonaniu - uchodziły za nauki pomocnicze historii? W wielu wypadkach konstatacja o „pomroce dziejów” w monografii ks. Nowackiego nie oznacza rezygnacji z podjęcia danej kwestii, ale jest wyrazem uczciwości w badaniu historyka, uczonego, dla którego właśnie stan źródeł stanowi granicę, ale nie limit jego dyskursu. J. Nowacki powierzył następnym pokoleniom historyków niezastąpioną monografię, pozwalającą na wgląd w materiał źródłowy, który właściwie przestudiowany może być następnie poprawnie interpretowany. Co więcej, studium dziejów katedry poznańskiej oraz struktur i granic archidiecezji poznańskiej stanowi nieocenione zaplecze dla kwestii, które mogą być postawione w przyszłości, albowiem „per praeterita cognoscentur futura". Ksiądz Nowacki przez swe główne dzieło jest również punktem odniesienia dla teologów i historyków dogmatu, chociaż kwestie te nie pojawiały się w obszarze jego prac ${ }^{20}$. Jego osiągnięcia zdają się potwierdzać konstatację Yves'a Congara, że znajomość historii pozbawia teologa wielu niepokojów i chroni przed uważaniem za tradycję tego, „co pochodzi z przedwczoraj”21. Dzięki znajomości źródeł historia staje się także materialną kulturą społeczności, w której obszarze historiografia może weryfikować samą siebie i oczyszczać się $\mathrm{z}$ ideologicznych skażeń.

\footnotetext{
19 Archiwum Archidiecezjalne w Poznaniu, Ordynariat Arcybiskupi, sygn. OA X 215.

${ }^{20}$ Wyjątek stanowi praca J. Nowackiego na zakończenie studiów, zatytułowana „De concilio Vaticano succincte et de quaestione controversa infallibilitatis Romani Pontificis in specie disseratur”, Poznań 1917 (maszynopis).

${ }^{21}$ Por. Y. Congar, Vraie et fausse réforme dans l'Église, Paris 1950 [tłum. R. Rybacki].
} 


\section{Historia Kościoła jako integralna część dyskursu nauk teologicznych i społecznych}

W zacytowanym powyżej studium poświęconym ks. prof. Marianowi Banaszakowi odnajdujemy bibliografię jego prac drukowanych ${ }^{22}$. Zawiera ona łącznie 626 pozycji z lat 1957-1997. Wśród tych prac naczelne miejsce zajmuje jego doktorat, poświęcony postaci Łukasza Kościeleckiego, biskupa poznańskiego w latach 1577-1597, a następnie rozprawa habilitacyjna, wydana pt. $Z$ dziejów dyplomacji watykańskiej. Poselstwa obediencyjne w latach 1534-160523. W swej „Autobiografii” ks. Banaszak tak wspomina pojawienie się idei prac nad tym zagadnieniem: ,[p]ojechałem do Warszawy, przed południem chodziłem do Archiwum Głównego Akt Dawnych, zainteresowany przede wszystkim Metryka Koronna, wskutek czego zaplanowałem sobie jako drugi temat badawczy poselstwa polskie do Rzymu w drugiej połowie XVI wieku"24. Drugim dziełem jest bez wątpienia pięciotomowa Historia Kościoła katolickiego wydawana w latach 1987-1992.

Dzieło to samo w sobie udziela w dużej mierze odpowiedzi na pytanie, w jaki sposób docieramy dzisiaj do specyfiki tego wyzwania, jakim była dla Kościoła jego własna historia, ujęta jako dyscyplina naukowa. Tej specyfiki w przypadku osoby ks. Banaszaka nie da się w pełni uchwycić bez uwzględnienia tego, że był on uczniem ks. Józefa Nowackiego. W zacytowanej już „Autobiografii” napisał o wpływie, jaki wywarł na niego jego nauczyciel historii Kościoła:

Wybitny historyk — czytamy — ks. Józef Nowacki, miał wywrzeć decydujący wpływ na moje naukowe ukierunkowanie, o czym wówczas nie wiedziałem. Jako naukowiec wsławił się monograficznym opracowaniem w dwóch tomach Dziejów Archidiecezji Poznańskiej, z których największe uznanie zdobył tom drugi: $A r$ chidiecezja Poznańska w historycznych granicach i jej ustrój. Ks. prof. E.H. Wyczawski z Akademii Teologii Katolickiej w Warszawie, wychwalając wartość tego tomu, powiedział na zjeździe historyków Kościoła, że dzisiaj żaden historyk sam jeden nie potrafi opracować takiego dzieła. O ks. prof. J. Nowackim, moim profesorze, jako nauczycielu i uczonym napisałem wspomnienia zaraz po jego śmierci i dołączyłem do drukowanego wówczas II tomu Dziejów Archidiecezji Poznańskiej ${ }^{25}$.

\footnotetext{
${ }^{22}$ Ecclesia Posnanienisis. Opuscula Mariano Banaszak septuagenario dedicata, red. F. Lenort, K. Lutyński, Poznań 1998, s. 287-319.

${ }_{23}$ M. Banaszak, Z dziejów dyplomacji watykańskiej. Poselstwa obediencyjne w latach 15341605, t. 1-3, Warszawa 1975.

${ }^{24}$ Ecclesia Posnaniensis..., s. 380.

${ }_{25}$ Tamże, s. 364.
} 
Ksiądz Banaszak dostrzegał potrzebę syntetycznego opracowania dziejów Kościoła katolickiego, aby opracowany z niezwykłą atencją i znawstwem przez ks. Nowackiego materiał źródłowy mógł teraz stanowić swoiste zaplecze w dyskusjach historiograficznych, które stopniowo odsłaniały swe tendencje do wkroczenia na obszar historii idei, duchowości, liturgii i prawa kościelnego. Już w 1968 roku ks. Banaszak był jednym ze znaczących interlokutorów w kwestii statutu prawnego biskupstwa w Poznaniu, powołanego do istnienia w 968 roku. Na łamach „Miesięcznika Kościelnego Archidiecezji Poznańskiej” opublikował kilka artykułów będących ważną częścią dyskusji w powyższej kwestii swoistej debaty, prowadzonej w pierwszej połowie XX wieku przez wybitnych przedstawicieli polskiego świata nauki ${ }^{26}$. Najobszerniejsza część wypowiedzi ks. Banaszaka dotyczyła charakteru prawnego biskupów Jordana i Ungera i została opublikowana w 1969 roku w „Naszej Przeszłości”27. Specyfikę historii Kościoła jako dyscypliny naukowej, dysponującej potężnym zasobem źródłowym, będącym — jak określił to papież Paweł VI — ,swoistym zapleczem psychologicznym dla przyszłości Kościoła”, można odkryć na płaszczyźnie historii idei. Słuszne wydaje się twierdzenie, że rozprawa ks. prof. Mariana Banaszaka, zatytułowana Chrześcijańska myśl i działalność społeczna w zaborze pruskim $1865-1918^{28}$ była swoistym preludium od jego pięciotomowej Historii Kościoła katolickiego.

We wstępie do pierwszego tomu tej edycji, w 1984 roku ksiądz Banaszak pisał, że celem historii Kościoła jest „naukowe przedstawienie dziejów Kościoła w eklezjologicznym, a nie jedynie strukturalnym ujęciu”29. Dzieje Kościoła czytamy dalej — „treściowo obejmują wewnętrzne i zewnętrzne życie Kościoła, jego struktury i wszystkie uwarunkowania: geograficzne, polityczne, społeczne, kulturalne i religijne"30. Dla historyka Kościoła kwestią metodologiczną niezwykle ważną są kryteria systematyzacji poruszanych zagadnień. Z pewnością w metodzie tejże systematyzacji, zaproponowanej na gruncie drugiego tomu Dziejów Archidiecezji Poznańskiej przez ks. prof. Józefa Nowackiego, ksiądz Marian Banaszak znalazł przynajmniej częściowe uzasadnienie do uporządkowania przedstawianych kwestii według kryteriów: rzeczowego, geograficznego i chronologicznego ${ }^{31}$. W tym miejscu można po części zestawić metodologię za-

\footnotetext{
${ }^{26}$ Zob. „Miesięcznik Kościelny Archidiecezji Poznańskiej”, 1968, nr 3, s. 103-116, nr 4, s. $136-142$, nr 5, s. 155-164.

${ }_{27}$ Zob. M. Banaszak, Charakter prawny biskupów Jordana i Ungera, „Nasza Przeszłość” 30 (1969), s. 43-123.

${ }^{28}$ Tenże, Chrześcijańska myśl i działalność społeczna w zaborze pruskim 1865-1918, w: Historia katolicyzmu społecznego w Polsce 1832-1939, red. C. Strzeszewski, R. Bender, K. Turowski, Warszawa 1981, s. 65-139.

29 Tenże, Historia Kościoła Katolickiego, t. 1, Warszawa 1986, s. 8.

30 Tamże.

${ }^{31}$ Zob. tamże, s. 9.
} 
stosowaną przez ks. Banaszaka na gruncie jego Historii Kościoła katolickiego z metodologią, którą spotykamy w Histoire du christianisme, liczącej dwanaście tomów edycji wydawanej od 1992 roku $^{32}$. Obraz procesu dziejowego Kościoła — jak stwierdził ks. Banaszak — ,wymaga najpierw ustalenia samych faktów (faktografia), następnie wyjaśnienia ich przyczyn (genetyzm) i ukazania skutków (pragmatyzm)"33. Szczególne wyzwanie, jakie stoi przed historią Kościoła jako nauką, ks. Banaszak określił następująco:

każdy historyk musi posłużyć się metodą naukową. Historyk Kościoła korzysta z ogólnej metody nauk historycznych, jednak powinien nadto uwzględnić specyfikę przedmiotu swoich badań, gdyż Kościół jest rzeczywistością złożoną, Bosko-ludzką. Nie może też w ocenach procesu dziejowego Kościoła pominąć kryteriów, wziętych z objawienia ${ }^{34}$.

\section{Konluzja}

Zarówno działalność naukowa ks. prof. Józefa Nowackiego, jak i ks. prof. Mariana Banaszaka, obok analizowania konkretnych kwestii związanych z rozwojem struktur kościelnych diecezji, a potem archidiecezji poznańskiej, była stopniowym ukazywaniem specyfiki historii Kościoła jako dyscypliny naukowej przez poszukiwanie nowych przedmiotów formalnych. W niniejszym przekonaniu specyfika danej dyscypliny naukowej, która jest rzeczywistością zakorzenioną w historii, wymaga nieustannej konfrontacji w rozszerzającej się przestrzeni interdyscyplinarności. Historia Kościoła bez odniesienia do materiału źródłowego, a co za tym idzie bez korzystania z rezultatów badań paleografii i dyplomatyki, pozostaje sekwencją przekazów wystawionych na ryzyko ideologicznego skażenia. Historia Kościoła ograniczona do badania samych dokumentów zostałaby pozbawiona tej żywotności, jaką może uzyskać w dialogu z innymi dziedzinami wiedzy. Zależność tę zrozumieli najpierw papież Leon XIII, potem kardynał Edmund Dalbor, a wraz z nimi poznańscy uczeni ks. Józef Nowacki i ks. Marian Banaszak. Stwierdzenie Huberta Jedina, że historia Kościoła pojęta jako dziedzina teologiczna pozostaje eklezjologią, stanowi odpowiedź na pytanie, w czym tkwi specyfika historii Kościoła i dlaczego jest ona szczególnym dla niego wyzwaniem.

${ }^{32}$ Zob. Histoire du christianisme, t. 1-12, ed. J.M. Mayeur et. al, Paris 1992-1999. Świadomie pomijam tutaj rozróżnienie pomiędzy historią Kościoła a historią chrześcijaństwa, gdyż wyjaśnienie tego problemu stanowi odrębną kwestię, w dużej mierze objaśnioną w literaturze przedmiotu; zob. m.in. R. Gustaw, Rozwój pojęcia historii Kościoła od I do XVIII wieku, Poznań-WarszawaLublin 1964

${ }_{33}$ M. Banaszak, Historia Kościoła Katolickiego, t. 1, s. 8.

34 Tamże. 


\section{History as a special challenge of the Church in the view of Józef Nowacki and Marian Banaszak}

\section{Summary}

In the presented article history is shown as a special challenge for the Church. The issue raised is presented in relation to historical research and didactic activity of two Polish historians, Józef Nowacki and Marian Banaszak. Two basic questions are asked: what is the specificity of the history of the Church in all theological disciplines? and: What is the basic requirement that this discipline is in the reality of the Church?

\section{Keywords}

Church history, Józef Nowacki, Marian Banaszak, Hubert Jedin, historical sciences, Church historiography

\section{Słowa kluczowe}

historia Kościoła, Józef Nowacki, Marian Banaszak, Hubert Jedin, nauki historyczne, historiografia kościelna

\section{Bibliografia}

Banaszak M., Charakter prawny biskupów Jordana i Ungera, „Nasza Przeszłość” 30 (1969), s. 43-123.

Banaszak M., Chrześcijańska myśl i działalność społeczna w zaborze pruskim 1865 1918, w: Historia katolicyzmu społecznego w Polsce 1832-1939, red. C. Strzeszewski, R. Bender, K. Turowski, Warszawa 1981, s. 65-139.

Banaszak M., Hipoteza o misyjnym charakterze biskupów Jordana i Ungera, „Miesięcznik Kościelny Archidiecezji Poznańskiej”, 19 (1968) 5, s. 155-164.

Banaszak M., Historia Kościoła Katolickiego, t. 1-4, Warszawa 1986-1992.

Banaszak M., Początki biskupstwa poznańskiego (Niektóre aspekty tezy ks. J. Nowackiego i jej uzupetnienie), „Miesięcznik Kościelny Archidiecezji Poznańskiej”, 19 (1968) 3, s. 103-116.

Banaszak M., Poznań siedzibą Jordana i Ungera, „Miesięcznik Kościelny Archidiecezji Poznańskiej”, 19 (1968) 4, s. 136-142.

Banaszak M., Zdziejów dyplomacji watykańskiej. Poselstwa obediencyjne w latach 1534-1605, t. 1-3, Warszawa 1975.

Codex diplomaticus Maioris Poloniae, t. 1-11, Poznań 1877-1999.

Concilium Tridentinum. Diariorum, Actorum, Epistolarum, Tractatuum nova Collectio, t. 1-13, Friburgi Brisgoviae 1901-1961. 
Congar Y., Vraie et fausse réforme dans l'Église, Paris 1950.

Dorna M., Mabillon i inni. Rzecz o powstaniu dyplomatyki, Poznań 2014.

Ecclesia Posnanienisis. Opuscula Mariano Banaszak septuagenario dedicata, red. F. Lenort, K. Lutyński, Poznań 1998.

Gustaw R., Rozwój pojęcia historii Kościoła od I do XVIII wieku, Poznań-WarszawaLublin 1964.

Histoire du christianisme, ed. J.M. Mayeur, Ch. Pietri, L. Pietri, A. Vauchez, M. Venard, t. 1-12, Paris 1992-1999.

Historia Kościoła od początku aż do naszych dni, t. 1: Kościół pierwotny, red. A. Fliche, W. Martin, tłum. J. Dembińska, Z. Czerniewiczowa, Lublin 1939.

Italia Pontificia sive repertorium privilegiorum et litterarum a Romanis Pontificibus ante annum MCLXXXXVIII Italiae ecclesiis, monasteris, civitatibus singulisque personis concessorum, t. I-VII, ed. P.F. Kehr, Berolini 1906-1925.

Jedin H., Girolamo Seripando. Sein Leben und Denken im Geisteskampf des 16. Jahrhunderts, t. 1-2, Würzburg 1937.

Lenort F., Z dziejów organizacji i zasobu Archiwum Archidiecezjalnego w Poznaniu, Lublin 1967.

Liber beneficiorum dioecesis Posnaniensis anni 1510, ed. J. Nowacki, t. X, Poznań 1950. Mabillon J., De Re diplomatica libri VI [...], Paryż 1681.

Martina G., L'apertura dell'Archivio Vaticano. Il significato di un centenario, „Archivum Historiae Pontificiae", 19 (1981), s. 239-307.

Nowacki J., De archiepiscopi gnesnensis dignitate ac praerogativa primatiali, Lwów 1937 [wyd. pol. O godności i uprawnieniach prymasowskich arcybiskupa gnieźnieńskiego, tłum. A. Strzelecka, Poznań 2008].

Nowacki J., „De concilio Vaticano succincte et de quaestione controversa infallibilitatis Romani Pontificis in specie disseratur", Poznań 1917 [maszynopis].

Nowacki J., Dzieje Archidiecezji Poznańskiej, t. 1: Kościół katedralny w Poznaniu. Studium historyczne, Poznań 1959, t. 2: Archidiecezja Poznańska w granicach historycznych i jej ustrój, Poznań 1964.

Pieszczoch S., Ksiądz Józef Nowacki jako patrolog, w: Ecclesia Posnaniensis. Opuscula Mariano Banaszak septuagenario dedicata, red. F. Lenort, K. Lutyński, Poznań 1998, s. 267-272.

Rauschen G., Patrologie. Die Schriften der Kirchenväter und Ihr Lehrgehalt, Freiburg im Breisgau 1925 [tłum. pol. J. Nowacki, Zarys patrologii. Pisma Ojców Kościoła i nauka w nich zawarta, Poznań 1929].

Tessitore F., Introduzione allo storicismo, Roma-Bari 1999. 